\title{
Alteration of Mother's Sexual Activity during Pregnancy
}

\author{
Erni Samutri ${ }^{1}$, Wenny Artanty Nisman², Wiwin Lismidiati
}

${ }^{1}$ Program of Nursing Science, Universitas Alma Ata, Jl. Brawijaya No.99 Yogyakarta ${ }^{2}$ Program of Nursing Science, Universitas Gadjah Mada, JI. Farmako Sekip Utara Yogyakarta Email : erni.samutri@almaata.ac.id

\begin{abstract}
Abstrak
Aktivitas seksual selama kehamilan merupakan salah satu isu penting bagi ibu hamil dan tenaga kesehatan, namun jarang diungkapkan. Penelitian pada topik ini telah dilakukan secara luas, namun masih belum ada kesimpulan yang seragam. Penelitian ini bertujuan untuk menganalisa perubahan aktivitas seksual ibu sebelum dan selama kehamilan dan mendeskripsikan sumber informasi yang diperoleh ibu terkait aktivitas seksual selama kehamilan. Penelitian cross-sectional ini dilakukan pada ibu hamil yang melakukan ANC di Puskesmas Tegalrejo Yogyakarta. Pemilihan sampel menggunakan quota sampling dengan total 78 ibu hamil (setiap trimester terdiri dari 26 ibu hamil) dan tidak memiliki masalah kesehatan khusus yang berhubungan dengan kehamilan (kehamilan resiko tinggi, perdarahan pervagina). Pengumpulan data menggunakan instrumen Pregnancy Sexuality and Response Inventory (PSRI) versi Indonesia dengan nilai Cronbach's alpha: 0.714. Data perubahan aktivitas seksual (aspek biologis, emosional, dan fisik) sebelum dan selama kehamilan pada setiap trimester dianalisa dengan paired t test. Data perubahan aktivitas sekusal antar trimester pada beberapa subaspek (frekuensi aktivitas seksual, desire, dan nyeri saat berhubungan) dianalisa dengan Kruskal wallis test dan dilanjutkan dengan post hoc test pada hasil analisa yang signifikan. Hasil penelitian menunjukkan adanya perubahan signifikan pada aspek biologis aktivitas seksual ibu hamil sebelum dan selama kehamilan, khususnya di trimester kedua ( $p$ 0.002) dan ketiga ( $p$ 0.000), dengan perubahan ke arah penurunan. Kemudian penurunan signifikan juga ditemukan pada aspek emosional pada semua trimester kehamilan $(p<0.05)$. Sejalan dengan aspek biologis, aspek fisik aktivitas sekusal juga mengalami penurunan signifikan di trimester kedua ( $p 0.000)$ dan ketiga ( $p 0.000)$. Ibu hamil memperoleh informasi mengenai aktivitas seksual selama kehamilan dari berbagai sumber, dan umumnya dari tenaga kesehatan (35.9\%). Pemberian informasi yang tepat terkait aktivitas seksual selama kehamilan akan membantu ibu untuk memahami perubahan aktivitas seksualnya dan membantu mengambil keputusan yang tepat terkait pilihan seksualnya selama kehamilan.
\end{abstract}

Kata Kunci: aktivitas seksual; kehamilan; ibu

Abstract
Sexual activity during pregnancy is one of the significant issues for both pregnant mother and healthcare provider, though rarely disclosed. Studies on this topic have been done broadly, though still no conclusion. The aim of this study was to analyze the change of mother's sexual activity before and during pregnancy and to describe resources used by mother to find sexual activity information. A descriptive cross sectional study was conducted on pregnant mothers who undergo antenatal care at Tegalrejo public health center, Yogyakarta. Sample was determined using quota sampling which total sample was 78 pregnant mothers (26 pregnant mothers per trimester) without significant health problem related to their pregnancy, such as high risk pregnancy condition and vaginal bleeding. Data were collected using Indonesian version of Pregnancy Sexuality and Response Inventory 
(PSRI) questionnaire which reliable to used (Cronbach's alpha: 0.714). Data on sexual activity (biological, emotional, and physical aspects) in each trimester were analyzed by paired t test. Data on sexual activity among trimesters in several sub-aspects (frequency, desire, and pain during intercourse) were analyzed by Kruskal wallis and followed by post hoc analysis on significant result. Result showed the significant changes of biological aspect of mother's sexual activity before and during pregnancy, especially in the second ( $p$ 0.002) and third trimester ( $p$ 0.000) and the changes tend to decline. Significant decline also found in emotional aspect of all trimesters $(p<0.05)$. In line with biological aspects, physical aspect also showed significant decline in the second ( $p$ 0.000) and third trimester (p 0.000). Pregnant mother got numerous resources related to sexual activities during pregnancy, yet the most common was from healthcare provider (35.9\%). Providing the right information related to this topic will help the mother to understand their sexual activity changes and to choose the right decision in performing sexual activity.

Keywords: sexual activity; pregnancy; mother

Article info:

Article submitted on January, 102020

Articles revised on February 11, 2020

Articles received on March 25, 2020

DOI: http://dx.doi.org/10.21927/jnki.2020.8(1).17-25

\section{INTRODUCTION}

Sexual health is an important aspect in achieving quality of life for both man and women (1). World Health Organization define sexual health as "a state of physical, mental and social well-being in relation to sexuality". Therefore, sexual health is not merely related to intimacy, being free from disease or dysfunction, more broadly it related to sexual activity, pleasant and safe sexual experience, and free from coercion; discrimination; and violation (2). Sexual activity include biological, emotional and physical aspects. Biological aspect ranges from holding hands, kissing the cheeks or lips, and developing to sexual intercourse. Emotional aspect is shown through the emotional attachment between partners, including sexual arousal, response to sexual stimulation, and sexual satisfaction. While the physical aspect related to medical condition, such as pain and psychological distress during sexual intercourse (3).

Sexual activity during pregnancy is one of the significant issues for both pregnant mother and health care provider, though rarely disclosed. Women's physical, psychological, and social changes will determine further sexual perception and practice along pregnancy (4). Women's complain related to their physical problem or discomfort during pregnancy may leads to avoidance of sexual intercourse during pregnancy. Deterioration of sexual activity during pregnancy due to the lack of understanding related to this topic may affect not only mother's physical health but also their psychological health, relationship with their spouse, and quality of life (5). Thus needed further evaluation about mother perception related sexual activity along pregnancy and their health concern during pregnancy.

Many studies on sexual activity during pregnancy have been done broadly, though still no conclusion. Sexual desire, orgasm and frequency of sexual activity during pregnancy show reduction compared to before pregnancy $(2,5)$. Tosun Güleroğlu \& Gördeles Beşer study found that sexual dysfunction generally experienced by pregnant mother are sexual desire disorder $(88,9 \%)$, arousal disorder $(86,9 \%)$, lubrication 
disorder $(42,8 \%)$, orgasm disorder $(69,6 \%)$, and sexual satisfaction disorder (48\%). Sexual dysfunction will increase along with an increase of gestational age (5). Kahlesi through prospective cohort study pointed the similar result that sexual function showed significant regression over time during pregnancy. Regression of sexual function mostly experienced on third trimester $(6,7)$. However, several previous studies showed vary result that experience of orgasm has no change during pregnancy, while others report that the achievement of orgasm decreases as well as the frequency of intercourse (8).

Religion and cultural boundaries are the general issue usually emerged by the researcher in assessing sexual activity during pregnancy $(9,10,11,12)$. Common perception that sexual activity is taboo to talk, also make it difficult to dig up $(9,11)$. Especially in Indonesia, research related to this topic is still limited. Several published studies conducted in Indonesia generally assess the mother attitude related to sexual activity dan sexual function during pregnancy. Cedli study on husband sexual function during pregnancy showed that the most of husband show decrease on their sex drive, erection and frequency of sexual activity. However, there was no change in sexual satisfaction (13). Study conducted by Tawulo found that the majority of mother show negative attitude related to sexual activity during pregnancy. Mother and their spouse choose abstinence especially in the last trimester (12). It could be related to cultural background which mother avoid to discussing about their sexual desire and needs $(9,12)$.

Preliminary observation showed that mother feel uncomfortable to discuss their sexual problem during pregnancy to physician or other healthcare provider. Midwife interviewed also stated that specific counseling related to this topics not been done yet. Jarnali \& Mosalanejad stated that majority of the mothers never discuss their sensitive topics to healthcare provider throughout their pregnancy (14). Perception about adverse effect of sexual activity during pregnancy such infection and afraid to harm the baby during intercourse are still grow in our community (15). Whereas, mothers openness to discuss about their sexual problem during pregnancy could help them to make the right decision and enhance their quality of life (16).

Understanding mother sexual activity during pregnancy in specific region, will helping healthcare provider to realize the change of mother's sexual function and directing health professionals to provide comprehensive care according to their needs (3). The purpose of this study is to analyze the change of mother's sexual activity before and during pregnancy and to describe resources used by mother to find information related to sexual activity during pregnancy.

\section{MATERIALS AND METHODS}

This cross sectional study was conducted on pregnant mother who receive antenatal care in Tegalrejo public health center. Sample was determined using quota sampling which total sample was 78 pregnant mothers (26 pregnant mothers per trimester) without significant health problem related to their pregnancy, such as high risk pregnancy condition and vaginal bleeding. Data was collected using Pregnancy Sexuality and Response Inventory (PSRI) questionnaire which has been translated to Indonesian and reliable to be used (Cronbach's alpha: 0.714).

Indonesian version of PSRI questionnaire consists of 34 questions ( 8 demographic questions, 26 sexual activity questions) that used to evaluate the change of sexual activity before and during pregnancy in every trimester and related health concern of pregnant mother. Data collection was done by questionnaire distribution to mother who undergo antenatal care in Tegalrejo public health center. The 
questionnaires were fulfilled by pregnant mother in the waiting room while waiting for their turn to be examined. Based on this study design, the questionnaire was distributed to pregnant mother based on their current gestational age or trimester until fulfill the study quota, which 26 pregnant mothers per trimester. Data collection accomplished one month. After that, the complete questionnaires added to the database for further analysis.

Data on mother's sexual activity (biological, emotional, and physical aspects) in each trimester were analyzed by paired t test. Data on mother's sexual activity among trimesters in several sub-aspects (frequency of intercourse, sexual desire, and pain during intercourse) were analyzed by Kruskal wallis and followed by post hoc analysis on significant statistic result. Resources of information related sexual activity during pregnancy was analyzed using frequency distribution or percentage.

\section{RESULT AND DISCUSSION}

This study engaged 78 pregnant mother suited with the inclusion criteria. Majority of respondents were multigravida $((56,4 \%)$ by age ranged from $20-30$ years old $(71,8 \%)$. This age range (20-30 years old) is an optimum age of women's reproductive system which usually characterized by high level of women attractiveness and sexual desire, also most likely to become pregnant after conception (14). Majority of participants $(83,3 \%)$ had more than secondary school education, means that will make it easier for participants to understand the purpose and content of the questionnaire.

About $39,7 \%$ participants still working when pregnant, yet will be on leave while labor is approaching. In order to maintain mothers' health, they need to do appropriate activity and exercise. They have an opportunity to performing their work activities, yet adequate rest must be fulfilled approximately 8 hours per day. This time

Table 1. Demographic of The Pregnant Mother

\begin{tabular}{|c|c|c|c|c|c|c|c|}
\hline Demographic Data & $\begin{array}{c}\text { Trimester } 1 \\
(\mathrm{n}=26)\end{array}$ & Mean \pm SD & $\begin{array}{c}\text { Trimester } 2 \\
(n=26)\end{array}$ & Mean \pm SD & $\begin{array}{c}\text { Trimester } 3 \\
(n=26)\end{array}$ & Mean \pm SD & Sig. \\
\hline $\begin{array}{l}\text { Mother's Age (y.o) } \\
-\quad<20 \\
-\quad 20-30 \\
-\quad>30\end{array}$ & $\begin{array}{c}0 \\
18(69,2 \%) \\
8(30,8 \%)\end{array}$ & $\begin{array}{c}0 \\
26,00 \pm 2,52 \\
33,13 \pm 3,31\end{array}$ & $\begin{array}{c}2(7,7 \%) \\
21(80,8 \%) \\
3(11,5 \%)\end{array}$ & $\begin{array}{l}18,00 \pm 0,00 \\
25,71 \pm 4,17 \\
33,33 \pm 1,53\end{array}$ & $\begin{array}{c}2(7,7 \%) \\
14(53,8 \%) \\
10(38,5 \%)\end{array}$ & $\begin{array}{l}18,50 \pm 0,71 \\
24,64 \pm 2,79 \\
34,00 \pm 2,49\end{array}$ & 0,089 \\
\hline Gestational Age (Month) & $26(100 \%)$ & $2,33 \pm 0,79$ & $26(100 \%)$ & $5,23 \pm 0,86$ & $26(100 \%)$ & $8,62 \pm 0,64$ & 0,053 \\
\hline $\begin{array}{l}\text { Education } \\
\text { - Primary school } \\
\text { - Secondary school } \\
\text { - High school }\end{array}$ & $\begin{array}{c}0 \\
24(92,3 \%) \\
2(7,7 \%)\end{array}$ & & $\begin{array}{c}2(7,7 \%) \\
19(73,1 \%) \\
5(19,2 \%)\end{array}$ & & $\begin{array}{c}1(3,9 \%) \\
22(84,6 \%) \\
3(11,5 \%)\end{array}$ & & 0,083 \\
\hline $\begin{array}{l}\text { Religion } \\
\text { - Islam } \\
\text { - } \text { Christian } \\
\text { - } \text { Others (Catholic) }\end{array}$ & $\begin{array}{c}26(100 \%) \\
0 \\
0\end{array}$ & & $\begin{array}{c}21(80,8 \%) \\
4(15,4 \%) \\
1(3,8 \%)\end{array}$ & & $\begin{array}{c}24(92,4 \%) \\
1(3,8 \%) \\
1(3,8 \%)\end{array}$ & & 0,116 \\
\hline $\begin{array}{l}\text { Working status } \\
\text { - Housewife } \\
\text { - Yes, still working } \\
\text { - Yes, , on leave }\end{array}$ & $\begin{array}{c}14(53,8 \%) \\
10(38,5 \%) \\
2(7,7 \%)\end{array}$ & & $\begin{array}{c}13(50 \%) \\
11(42,3 \%) \\
2(7,7 \%)\end{array}$ & & $\begin{array}{c}12(46,1 \%) \\
10(38,5 \%) \\
4(15,4 \%)\end{array}$ & & 0,686 \\
\hline $\begin{array}{l}\text { Parities } \\
\text { - Not yet } \\
\text { - One } \\
\text { - Two or more }\end{array}$ & $\begin{array}{l}10(38,5 \%) \\
9(34,6 \%) \\
7(26,9 \%)\end{array}$ & & $\begin{array}{c}17(65,4 \%) \\
8(30,8 \%) \\
1(3,8 \%)\end{array}$ & & $\begin{array}{c}7(26,9 \%) \\
14(53,9 \%) \\
5(19,2 \%)\end{array}$ & & 0,168 \\
\hline $\begin{array}{l}\text { Cigarette consumption } \\
\text { - Yes, often } \\
\text { - Yes, sometimes } \\
\text { - Never }\end{array}$ & $\begin{array}{c}0 \\
1(3,8 \%) \\
25(96,2 \%)\end{array}$ & & $\begin{array}{c}0 \\
0 \\
26(100 \%)\end{array}$ & & $\begin{array}{c}0 \\
0 \\
26(100 \%)\end{array}$ & & - \\
\hline
\end{tabular}


will give opportunity to mother and their spouse to expressing their love, through such sexual activity. High workload and stress will impact on the length of working time and hormonal disorder which may disturb maternal health, such abortion or premature labor (15). Only 1,3\% participants who active smoking. Centers for Disease Control and Prevention (CDC) state that smoking during pregnancy will increase the risk of fetal problem and their development, includes preterm birth, low birth weight, birth defects of the mouth and lips. In addition, smoking behavior that undergo until the baby birth would increase the risk of sudden infant death syndrome (SIDS) (16). Demographic data is showed in table 1.

Homogeneity test of demographic data showed that almost all of participants have homogeneous characteristics ( $p>0,05)$, except cigarette consumption. Thus, data on sexual activity among trimesters can be tested.

\section{The Change of Biological Aspect}

Biological aspect of sexual activity consists of intercourse's frequency, orgasm, and the initiation of intercourse. Frequency of intercourse generally chosen by mother was 1-2 times per week for all trimesters and abstinence was increasing along with gestational age increase. Similar, experience of orgasm also showed decline as long as gestational age increase. Overall, Table 2 showed significant decrease of biological aspect of mother's sexual activity especially in second and third trimester $(p<0,05)$ compared before pregnancy. In addition, analysis of intercourse frequency among trimesters showed no significant differences $(p=0,143)$, yet appear decrease throughout pregnancy as showed in Table 3.

Finding of decline intercourse frequency on this study has similar result with previous studies $(5,10)$. The main reason for this decline are mother's fear to harm the fetus, bleeding or other negative effects, and physical discomfort $(1,10)$. Even, some mother and spouse decided to abstinence. In fact, abstinence is only recommended for pregnancy with specific condition which may bring harm to the mother and/or fetus such antepartum hemorrhage due

Table 3. Comparison of Biological Aspect (Frequency) of Sexual Activity among Trimesters

\begin{tabular}{lllll}
\hline & & $\mathrm{n}$ & Mean & $\mathrm{p}$-value \\
\hline Trimester & 1 & 26 & 1,730 & 0,143 \\
& 2 & 26 & 1,577 & \\
& 3 & 26 & 1,423 & \\
\hline
\end{tabular}

Kruskal wallis test

Table 2. Biological Aspect of Sexual Activity Before and During Pregnancy

\begin{tabular}{|c|c|c|c|c|c|c|}
\hline $\begin{array}{c}\text { Biological Aspect of } \\
\text { Sexual Activity }\end{array}$ & $\begin{array}{c}\text { Before } \\
\text { Pregnancy }\end{array}$ & $\begin{array}{c}\text { During } \\
\text { Trimester } 1 \\
\end{array}$ & $\begin{array}{c}\text { Before } \\
\text { Pregnancy }\end{array}$ & $\begin{array}{c}\text { During } \\
\text { Trimester } 2 \\
\end{array}$ & $\begin{array}{c}\text { Before } \\
\text { Pregnancy }\end{array}$ & $\begin{array}{c}\text { During } \\
\text { Trimester } 3\end{array}$ \\
\hline \multicolumn{7}{|l|}{ Frequency } \\
\hline - Abstinence & 0 & $2(7,7)$ & $1(3,8)$ & $5(19,2)$ & 0 & $8(30,8)$ \\
\hline - $\quad 1-2$ times & $20(76,9)$ & $21(80,8)$ & $15(57,7)$ & $17(65,4)$ & $18(69,2)$ & $14(53,8)$ \\
\hline - $\quad$ More than 3 times & $6(23,1)$ & $3(11,5)$ & $10(38,5)$ & $4(15,4)$ & $8(30,8)$ & $4(15,4)$ \\
\hline \multicolumn{7}{|l|}{ Orgasm } \\
\hline - Never/ rarely & $1(3,8)$ & $2(7,7)$ & $2(7,7)$ & $7(26,9)$ & 0 & $4(15,4)$ \\
\hline - Sometimes & $14(53,9)$ & $14(53,8)$ & $16(61,5)$ & $15(57,7)$ & $11(42,3)$ & $17(65,4)$ \\
\hline - Often & $11(42,3)$ & $10(38,5)$ & $8(30,8)$ & $4(15,4)$ & $15(57,7)$ & $5(19,2)$ \\
\hline \multicolumn{7}{|l|}{ The initiation of intercourse } \\
\hline - Forced & 0 & $1(3,8)$ & 0 & $2(7,7)$ & 0 & $1(3,8)$ \\
\hline - Initial move from partner & $13(50,0)$ & $12(46,2)$ & $11(42,3)$ & $13(50,0)$ & $14(53,8)$ & $17(65,4)$ \\
\hline $\begin{array}{l}\text { - Spontaneously with } \\
\text { stimuli }\end{array}$ & $13(50,0)$ & $13(50,0)$ & $15(57,7)$ & $11(42,3)$ & $12(46,2)$ & $8(30,8)$ \\
\hline $\begin{array}{l}\text { Comparison of biological } \\
\text { aspect }\end{array}$ & 0,161 & & 0,002 & & 0,000 & \\
\hline
\end{tabular}

Paired $t$ test 
to placenta previa. Physical discomforts would increase their intercourse limitation, especially at the last trimester (1).

Experience of orgasm reduced when compared to before pregnancy, especially at third trimester. This finding also revealed by several previous studies $(6,17,18)$. On the last trimester, enlarged tummy, cramps, fetal weight gain, anxiety and the natural fear related to the labor tend to aggravate mothers' physical discomfort, sexual desire and may decrease their orgasm experience (17).

However, several previous studies showed opposite result that experience of orgasm increases during pregnancy. It may be caused by development of genital blood flow. Blood flow that focused on fetal development also influence the intensity of orgasm during sexual intercourse compared to before pregnancy, especially in the second trimester. Yet, when pregnancy goes to the last trimester, various physical and psychological discomfort would decrease almost all sexual activity aspects (4).

Generally, this study show decrease of biological aspect of sexual activity experienced by pregnant mother, especially on the third trimester. However, mother with low-risk pregnancy are expected to feel comfortable to performing their sexuality (e.g. sexual intercourse) during pregnancy and not to worry to their negative thought (19).

\section{The Change of Emotional Aspect}

Emotional aspect of sexual activity includes desire, arousal, and satisfaction during sexual activity. Table 4 show the significant change on emotional aspect during all trimester $(p<0,05)$.

Comparison of sexual desire among trimesters showed difference along gestational age and showed significant decrease on the second and third trimester. However, we found increase of sexual desire when comparison done to before and during pregnancy, especially on the second trimester. This finding in line with several previous studies $(6,18)$.

The Second trimester is describes as the most stable period of mother emotional health, where the pregnancy is already recognized by others. Several problems such as fatigue, nausea, breast discomfort and the feeling

Table 4. Emotional Aspect of Sexual Activity Before and During Pregnancy

\begin{tabular}{|c|c|c|c|c|c|c|}
\hline $\begin{array}{c}\text { Emotional Aspect of Sexual } \\
\text { Activity }\end{array}$ & $\begin{array}{c}\text { Before } \\
\text { Pregnancy }\end{array}$ & $\begin{array}{c}\text { During } \\
\text { Trimester } 1\end{array}$ & $\begin{array}{c}\text { Before } \\
\text { Pregnancy }\end{array}$ & $\begin{array}{c}\text { During } \\
\text { Trimester } 2\end{array}$ & $\begin{array}{c}\text { Before } \\
\text { Pregnancy }\end{array}$ & $\begin{array}{c}\text { During } \\
\text { Trimester } 3\end{array}$ \\
\hline \multicolumn{7}{|l|}{ Sexual desire } \\
\hline - A few times a week & $4(15,4)$ & $5(19,2)$ & $12(46,2)$ & $7(26,9)$ & $9(34,6)$ & $6(23,1)$ \\
\hline - Once a day & 0 & $1(3,8)$ & 0 & 0 & 0 & 0 \\
\hline - Other (depend on the occasion) & $22(84,6)$ & $20(77)$ & $14(53,8)$ & $19(73,1)$ & $17(65,4)$ & $20(76,9)$ \\
\hline \multicolumn{7}{|l|}{ Arousal } \\
\hline - Poor/ very poor & 0 & $1(3,8)$ & 0 & $3(11,6)$ & $1(3,8)$ & 0 \\
\hline - Regular & $17(65,4)$ & $20(77)$ & $18(69,2)$ & $18(69,2)$ & $19(73,1)$ & $23(88,5)$ \\
\hline - Excellent & $9(34,6)$ & $5(19,2)$ & $8(30,8)$ & $5(19,2)$ & $6(23,1)$ & $3(11,5)$ \\
\hline \multicolumn{7}{|l|}{ Mothers' satisfaction } \\
\hline$-\quad$ No & 0 & $1(3,8)$ & 0 & $5(19,2)$ & $1(3,8)$ & $5(19,2)$ \\
\hline - Somewhat & $2(7,7)$ & $2(7,7)$ & $3(11,5)$ & $6(23,1)$ & $1(3,8)$ & $8(30,8)$ \\
\hline - Yes & $24(92,3)$ & $23(88,5)$ & $23(88,5)$ & $15(57,7)$ & $24(92,4)$ & $13(50,0)$ \\
\hline \multicolumn{7}{|l|}{ Satisfaction score } \\
\hline$-\quad 0-3$ & $6(23,1)$ & $9(34,6)$ & $8(30,8)$ & $13(50,0)$ & $8(30,8)$ & $12(46,2)$ \\
\hline$-\quad 4-7$ & $13(50,0)$ & $12(46,2)$ & $10(38,4)$ & $10(38,5)$ & $13(50,0)$ & $11(42,3)$ \\
\hline$-8-10$ & $7(26,9)$ & $5(19,2)$ & $8(30,8)$ & $3(11,5)$ & $5(19,2)$ & $3(11,5)$ \\
\hline - Comparison of emotional aspect & 0,016 & & 0,023 & & 0,035 & \\
\hline
\end{tabular}

Paired t test 
Table 5. Comparison of Emotional Aspect (Desire) of Sexual Activity among Trimesters

\begin{tabular}{lllll}
\hline & & $\mathbf{n}$ & Mean & p-value \\
\hline Trimester & 1 & 26 & 1,923 & 0,018 \\
& 2 & 26 & 1,615 & \\
& 3 & 26 & 1,423 & \\
\hline
\end{tabular}

Kruskal wallis test. Post hoc with Mann-Whitney: Trimester 1 vs. $2 p=0,079$; trimester 1 vs. $3 p<0,05$; trimester 2 vs. $3 p=0,346$

of harming the baby have faded away. In addition, the narrowing of genital area results in development of mother's sexual desire at the second and third trimester (5).

Sexual satisfaction also showed decline during pregnancy, especially in the last trimester and has supported several previous studies $(5,19)$. During the third trimester, pregnant mother and spouse would avoid sexual intercourse, due to various condition such as uterus contraction, feeling of harming the baby, decrease of libido, fatigue, pain during intercourse, and several pathological condition (e.g. premature rupture of membrane, placenta previa) $(6,20)$. Thus, mother and spouse cannot fully enjoy their sexual intercourse and results in decreased sexual satisfaction (21).

\section{The Change of Physical Aspect}

Physical aspect that consists of pain during intercourse (dyspareunia) and difficulties during sexual intercourse showed significant change in second and third trimester $(p<0,05)$ when compared to before pregnancy. The comparison of physical aspect among trimesters also shows significant change (decline), especially on the second and third trimester. This finding also supports previous studies (18). Physiological change of pregnant mother such as enlarged abdomen, fetal weight gain and the use of muscle that rarely used before pregnancy would results in imbalance posture, lumbar pain and difficult sexual intercourse that generally experienced during third trimester $(6,18)$.

Vice versa, study by Fejra stated that there is no difference of dyspareunia experience both before and during pregnancy, but the reason not stated. In order to ease dyspareunia experience, the right health suggestion such as comfort position during intercourse and noncoital sexual activity may benefit for mother and spouse (18). Anzaku study showed that pregnant mother prefers side-by-side sexual position than traditional husband on top position during intercourse. Side-by-side position will accomodate the increasing size of the abdomen and decrease the risk of fetal hypoxia (22).

Table 7. Comparison of Physical Aspect (Pain) of Sexual Activity among Trimesters

\begin{tabular}{llccc}
\hline & & $\mathbf{n}$ & Mean & p-value \\
\hline Trimester & 1 & 26 & 3,000 & 0,039 \\
& 2 & 26 & 2,769 & \\
& 3 & 26 & 2,692 & \\
\hline
\end{tabular}

Kruskal wallis test. Post hoc with Mann-Whitney: Trimester 1 vs. $2 p<0,05$; trimester 1 vs. $3 p<0,05$; trimester 2 vs. $3 p=0,700$

Table 6. Physical Aspect of Sexual Activity Before and During Pregnancy

\begin{tabular}{lcccccc}
\hline $\begin{array}{c}\text { Emotional Aspect of Sexual } \\
\text { Activity }\end{array}$ & $\begin{array}{c}\text { Before } \\
\text { Pregnancy }\end{array}$ & $\begin{array}{c}\text { During } \\
\text { Trimester 1 }\end{array}$ & $\begin{array}{c}\text { Before } \\
\text { Pregnancy }\end{array}$ & $\begin{array}{c}\text { During } \\
\text { Trimester 2 }\end{array}$ & $\begin{array}{c}\text { Before } \\
\text { Pregnancy }\end{array}$ & $\begin{array}{c}\text { During } \\
\text { Trimester 3 }\end{array}$ \\
\hline $\begin{array}{l}\text { Pain (dyspareunia) } \\
\text { - Yes }\end{array}$ & $5(19,2)$ & $5(19,2)$ & $2(7,7)$ & $10(38,5)$ & $3(11,5)$ & $11(42,3)$ \\
$-\quad$ No & $21(80,8)$ & $21(80,8)$ & $24(92,3)$ & $16(61,5)$ & $23(88,5)$ & $15(57,7)$ \\
Difficulties & & & & & & \\
$-\quad$ Yes & 0 & $3(11,5)$ & 0 & $12(46,2)$ & 0 & $13(50,0)$ \\
$-\quad$ No & $26(100)$ & $23(88,5)$ & $26(100)$ & $14(53,8)$ & $26(100)$ & $13(50,0)$ \\
$-\quad$ Comparison of physical & 0,416 & & 0,000 & & 0,000 & \\
$\quad$ aspect & & & & & &
\end{tabular}

Paired t test 
Information Sources Related to Sexual Activity during Pregnancy

Sources of information related sexual activity during pregnancy in this study listed from many sources which the most popular was from physician or other health care provider $(35,9 \%)$, followed by other resources such as from books $(28,2 \%)$, friends or neighbors $(15,45 \%)$, others $(15,4 \%)$ and more than one resources $(5,1 \%)$.

Cultural perspective that considered taboo to discuss sexual activity makes pregnant mother uncomfortable to consulting it with health care provider. Therefore, health care providers are responsible to deliver the right and comprehensive consultation related to this topic for both pregnant mother and spouse. In addition, they have to open the discussion first, thus give opportunities for pregnant mother to feel open and comfortable in revealing their problem.

Generally, sexual activity during pregnancy showed decrease throughout gestational age for all aspect (biological, emotional, and physical). Actually there are no standard for sexual activity, means everything related to sexual activity called normal when both side feels comfortable (17). However, their worries about fetal wellbeing and their labor would make the mother and spouse feel doubt in doing sexual intercourse and decrease sexual satisfaction during intercourse. Thus, sexual activity during pregnancy is one of the important consultation topic should be given by health care provider.

This study has several limitations. First, the data collection method was done through cross sectional. Thus, the study result could not analyze mother sexual activity over period of time (along preconception, pregnancy, and postpartum period). In addition, this design may leads to recall bias and could not guaranteed to be representative. Second, the number of sample for each trimester was limited. Therefore, further study need to be done with more advance design such as cohort design with more extensive sample. This strategy may reduce the possibility of recall bias and improve the generalizability of findings.

\section{CONCLUSION AND RECOMMENDATION}

All aspects of mother's sexual activity during pregnancy showed several changes when compared before and during pregnancy. This change tends to be similar for all trimesters, means that mother's sexual activity during pregnancy showed decline trend when compared to pre-pregnancy. In addition, comparison of sexual activity among trimesters also showed decline trend, such as intercourse frequency; desire and mother's difficulties during intercourse, especially during the last trimester. Providing the right information and consultation related to this topic might help the mother to understand their physiological change related to sexual activity and help the mother and their spouse to choose the right decision in performing sexual activity during pregnancy.

\section{REFERENCES}

1. Flynn KE, Lin L, Bruner DW, et al. Sexual Satisfaction and the Importance of Sexual Health to Quality of Life Throughout the Life Course of US Adults. J Sex Med. 2016 Nov; 13(11): 1642-1650.

2. World Health Organization. Sexual Health. 2019. https://www.who.int/topics/sexual_ health/en/

3. Wikipedians. Interpersonal Relationship. United State: PediaPress. 2018.

4. Zakšek TS. Sexual Activity during Pregnancy in Childbirth and after Childbirth. Sexology in Midwifery, Ana Polona Mivsek, IntechOpen. 2015; Chapter 5.

5. Tosun Guleroglu F, Gordeles Beser N. Evaluation of sexual functions of the pregnant women. J Sex Med. 2014; 11(1):146-153.

6. Khalesi ZB, Bokaie M, Attari SM. Effect of pregnancy on sexual function of couples. 
Afri Health Sci. 2018;18(2): 227-234. https:// dx.doi.org/10.4314/ahs.v18i2.5

7. Ahmadi Z, Malekzadegan A, Hosseini A. Sexual satisfaction and its related factors in primigravidas. Iran J Nurs. 2011;24(71):5462.

8. EL-Gharib MN. Orgasm During Pregnancy. Gynaecology and Perinatology. 2018; 2 (2): 264-266.

9. Torkestani F,-Hadavand S, Khodashenase Z, Besharat S, Davati A, Karimi Z, Zafarghandi N. Frequency and Perception of Sexual Activity during Pregnancy in Iranian Couples. Int J Fertil Steril. 2012; 6(2): 107-110.

10. Sossah L. Sexual behavior during pregnancy: a descriptive correlational study among pregnant women. European Journal of Research in Medical Sciences.2014; 2(1): 16-27.

11. Makara-Studzińska M, Plewik I, Krys KM. Sexual activity of women in different trimesters of pregnancy. EJMT. 2015; 2(7): 1-9.

12. Tawulo IK. Sikap Ibu Hamil tentang Aktivitas Seksual Selama Kehamilan di Puskesmas Puuwatu Kota Kendari Tahun 2017[Karya Tulis IImiah]. Kendari: Jurusan Kebidanan Politeknik Kesehatan Kendari. 2017.

13. Cedli LG. Fungsi seksual suami selama kehamilan pasangan [skripsi]. Jakarta: Fakultas IImu Keperawatan Universitas Indonesia;2012.

14. Jamali S, Mosalanejad L. Sexual dysfunction in Iranian pregnant women. Iran J Reprod Med. 2013;11(6):479-86.

15. Ebrahimian A, Heydari M, Saberi Zafar Ghandi MB, Delavari S. Comparing Sexual dysfunctions in men before and during their wife's pregnancy. Iran J Obstet Gynecol Infertil. 2012;15(33):19-25.

16. Centers for Disease Control and Prevention (CDC). Substance abuse during pregnancy. 2019. CDC. https://www.cdc.gov/ reproductivehealth/maternalinfanthealth/ substance-abuse/substance-abuse-duringpregnancy.htm

17. Erbil N. Sexual function of pregnant women in the third trimester. Alexandria Journal of Medicine. 2018; 54:139-42.

18. Fejza $H$, Icka E, Alilaj $M$, Elezi M, Fejza $A$, Jemini, L. Assessing the Impact of Pregnancy on Sexuality Using the Pregnancy Sexual Response Inventory. Advances in Sexual Medicine. 2018; 8: 15-24.

19. Claire Jones MD, Crystal Chan MD, Dan Farine MD. Sex in pregnancy. CMAJ 2011;183(7):815-8.

20. Corbacioglu-Esmer A, Akca A, Akbayir O, Cilesiz-Goksedef BP, Bakir VL. Female sexual function and associated factors during pregnancy. J Obstet Gynaecol Res. 2013;39:1165-1172.

21. Heidari $M$, Amin Shokravi $F$, Zayeri $F$, Azin SA, Merghati-Khoei E. Sexual life during pregnancy: effect of an educational intervention on the sexuality of Iranian couples: a quasi-experimental study. J Sex Marital Ther. 2017:1-11.

22. Anzaku AS, Ngozi OF, Dabu BA, Edet EB. Frequency, perceptions and complications of sexual activity during pregnancy among a group of Nigerian women. International Archives of Integrated Medicine. 2015;2(6): 54-63. 